\section{Selection for diploid cells in suspension cultures of Haplopappus gracilis}

Changes in the number and structure of chromosomes of plant cells cultured in vitro are of common occurrence ${ }^{\mathrm{I}}$, and cell populations devoid of diploid karyotype have been reported ${ }^{2-4}$. The chromosome number is known to become variable even in clones derived from single cells ${ }^{5,6}$. In the case of Picea glauca Voss. $(n=21)$ callus cultures, a positive correlation between growth rate and chromosome number was observed ${ }^{7}$, which indicates a selection for polyploid cells. Only diploid cells were, however, observed in mitosis in suspension cultures of Haplopappus gracilis (Nutt.) Gray $(n=2)$ (ref. 2), Medicago sativa L. $(n=16)$ (ref. 8$)$ and Crepis capillaris L. Wallr. $(n=3)$ (ref. 9). This could result from polyploid cells dividing less frequently than diploid cells, as diploid and polyploid cells differ physiologically. A strong selection for diploid cells was observed ${ }^{10}$ in Vicia hajastana Grossh. $(n=5)$ suspension cultures initiated from mature seeds. It therefore seemed likely that cell cultures of other plant species with a low chromosome number, $n=7$ or less, would show a selection for diploid cells.

Callus cultures were initiated from hypocotyl segments of 3-d-old seedlings of $\mathrm{H}$. gracilis on agar $\mathrm{B} 5$ medium $^{11}$ containing $4.5 \times 10^{-6} \mathrm{M}$ 2,4-dichlorophenoxyacetic acid (2,4-D) The calli were kept in a culture room at constant temperature $\left(27-28^{\circ} \mathrm{C}\right)$ and light $(2,000 \mathrm{~lx})$. Subculturing was carried out every 3 weeks. After $122 \mathrm{~d}$ in culture, some cells were transferred to liquid B5 medium with 2,4-D at the same concentration. The suspension cultures were subcultured every $3 \mathrm{~d}$, and were agitated by a gyratory shaker at 150 r.p.m. The cytological technique was essentially that of Singh et al. ${ }^{10}$.

An increase in the frequency of aneuploid cells was observed after $94 \mathrm{~d}$ in culture; a drastic decrease subsequently occurred. The frequency of diploid cells increased consistently whereas that of tetraploid cells steadily declined (Table 1). Anaphase analyses revealed a number of anomalies, such as bridges, fragments, unequal distribution of chromatids and laggards in low frequencies $(1-3 \%)$. Chromosomes with altered mor-

Table 1 Frequencies ( $\%$ ) of different cell types in two suspension cultures ( $\mathrm{A}$ and $\mathrm{B})$ of $H$. gracilis

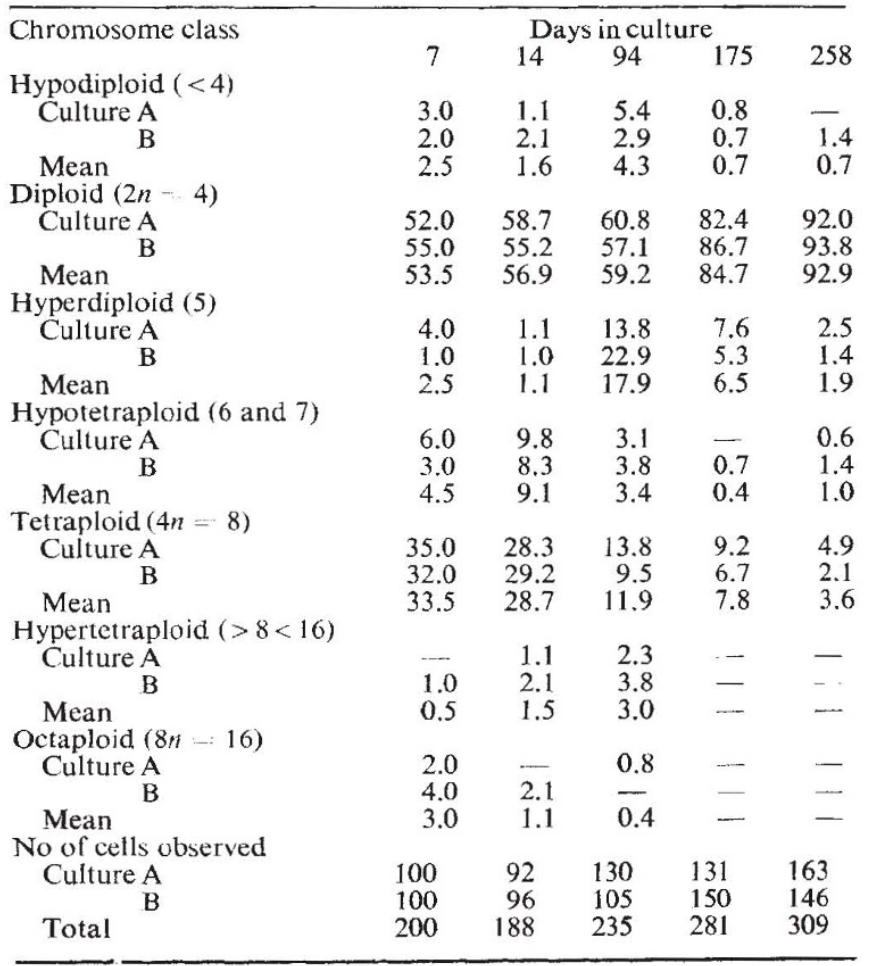

phology were also observed at metaphase. These anomalies could have been induced by $2,4-\mathrm{D}$, or some other factor, present in the culture medium, and would lead to the production of aneuploid cells from diploid and polyploid cells. Furthermore, endoreduplication is likely to occur in plant cells cultured in vitro ${ }^{12,13}$. The increase in the frequency of diploid cells under such a condition, therefore, clearly shows a strong selection for such cells. A similar selection for diploid cells was observed in suspension cultures of $H$. ravenii $(n=4)$, a closely related species, initiated from stem segments ${ }^{14}$.

The cytogenetic behaviour of $H$. gracilis cells has been investigated previously $2,15-18$. In some studies, a systematic analysis of the changes in the frequencies of various karyotypes during the in vitro culture was not made $\mathrm{e}^{2,16,17}$, but where such an analysis was made ${ }^{15,18}$, an increase in the frequency of polyploid cells was observed. Since agar media were used ${ }^{15,18}$, these findings do not necessarily contradict the results reported here. An increase in the frequency of polyploid cells was observed when $H$. gracilis cells were cultured on agar B5 medium $^{19}$. Only diploid cells were observed in a suspension culture of $H$. gracilis, which was interpreted to indicate a selection for diploid cells ${ }^{2}$.

The distribution of the two chromosomes of $H$. gracilis in the aneuploid cells was non-random; chromosome I was present more often than expected. In fact, almost all of the cells with five chromosomes had an extra chromosome I. A similar non-random distribution of chromosomes has been observed in suspension cultures of $V$. hajastan $a^{10}$. Since both chromosome I and II seem to be equally susceptible to mitotic irregularities, it seems that cells possessing an extra chromosome I were at a selective advantage over those possessing an extra chromosome II.

The present study was carried out at Crop Science Department, University of Saskatchewan, Saskatoon, Canada, and was supported by the National Research Council of Canada. We thank Dr R. Tanaka, Hiroshima, for a gift of $H$. gracilis seeds.

Department of Genetics and Plant Breeding,

B. D. SINGH

Banaras Hindu University,

Varanasi 221005, India

B. L. HARVEY

Crop Science Department,

University of Saskatchewan,

Saskatoon, Saskatchewan, Canada

Received October 18; revised December 9, 1974.

1 Partanen, C. R., Int. Rev. Cytol, 15, 215-243 (1963).

2 Kao, K. N., Miller, R. A., Gamborg, O. L., and Harvey, B. L., Can. J. Genet, Cytol. 12, 297-301 (1970).

3 Torrey, J. G., Physiologia Plant., 20, 265-275 (1967).

4 Singh, B. D., Caryologia (in the press).
5 Cooper, L. S., Cooper, D. C., Hildebrandt, A. C., and Riker, A. J., Am. J. Bot., 51. 284-290(1964).

Muir, W. H., Proc. int. Conf. Plant Tissue Culture (edit. by White, P. R., and Grove, A. R.), 485-490 (McCutchan, Berkley, 1965).

7 DeTorok, D., and Roderick, T. H., Cancer Res., 22, 174-181 (1962).

Clement, W. H., Am. J. Bot., 5 I, 670 (1964).

9 Reinert, J., and Kuster, H. J., Z. Pflanzenphysiol., 54, 213-222 (1966).

10 Singh, B. D., Harvey, B. L., Kao, K. N., and Milier, R. A., Can. J. Genet. Cytol.,

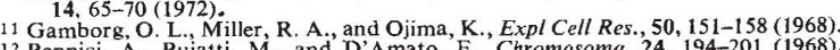
12 Bennici, A., Buiatti, M., and D'Amato, F., Chromosoma, 24, 194-201 (1968) 13 D'Amato, F., Proc. int. Conf. Plant Tissue Culture, (edit. by White, P. R., and Grove, A. R.), 449-462 (McCutchan, Berkeley, 1965).

15 Bennici, A., Buiatti, M., D'Amato, F., and Pagliai, M., Les Cultures de Tissues

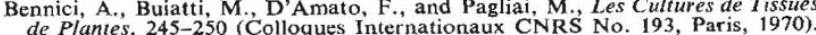
${ }_{16}$ Mitra, J., and Steward, F. C., Am. J. Bot., 48, 358-368 (1961).

17 Reinert, J., and Torrey, J. G., Naturwissenschaften, 48, 132-133 (1961).

18 Shamina, Ż. B., Proc. Symp. on the Mutational Process (edit. by Landa, Z.), 377-380 (Academia, Prague, 1966).

19 Singh, B. D., and Harvey, B. L., Cytologia (in the press).

\section{Lack of permeability of mouse placenta to maternal and foetal cells}

IN man, foetal leukocytes circulate in the maternal blood in most pregnancies and are occasionally detected up to $1 \mathrm{yr}$ after delivery ${ }^{1-3}$. On the other hand, maternal white blood corpuscles have seldom been found in the foetal 